\title{
Serum biomarkers of tubal ectopic pregnancy: current candidates and future possibilities
}

\author{
Joanna Cartwright, W Colin Duncan, Hilary O D Critchley and Andrew W Horne \\ Division of Reproductive and Developmental Sciences, Simpson Centre for Reproductive Health, \\ The University of Edinburgh, Royal Infirmary of Edinburgh, 51 Little France Crescent, Edinburgh EH16 4SB, UK \\ Correspondence should be addressed to A W Horne; Email: andrew.horne@ed.ac.uk
}

\begin{abstract}
Ectopic pregnancy remains a considerable cause of maternal morbidity and mortality worldwide. Currently, it is diagnosed using a combination of transvaginal ultrasound and serial serum $\boldsymbol{\beta}$-human chorionic gonadotrophin levels. Diagnosis is often delayed and these tests are time-consuming and costly, both psychologically to the patient and financially to health services. The development of a biomarker that can differentiate a tubal ectopic from an intrauterine implantation is therefore important. In the pre-genomic era, a one-by-one scientific approach has revealed over 20 candidate biomarkers that could be used as a test to diagnose ectopic pregnancy although at present their clinical utility is very limited. These biomarkers cluster into themes: markers of abnormal embryo/trophoblast growth, markers of abnormal corpus luteum function, markers of a growing pregnancy in the Fallopian tube, markers of inflammation and peritoneal irritation, and uterine markers of normal implantation. It is likely that this thematic approach will facilitate the identification of newer biomarkers using microarray technology and inform the development of investigative paradigms using multiple markers at the time of presentation.

Reproduction (2009) 138 9-22
\end{abstract}

\section{Introduction}

Tubal ectopic pregnancy is an important cause of maternal morbidity that can be fatal if left undiagnosed due to the risk of potential tubal rupture and haemorrhage. Every year in the UK there are $\sim 11000$ cases of tubal ectopic pregnancy (11.5 per 1000 pregnancies) and four maternal deaths due to ruptured tubal ectopic pregnancies (0.4 per 1000 tubal ectopic pregnancies; Tay et al. 2000, Lewis 2007). The incidence of tubal ectopic pregnancy is increasing not only in the UK but worldwide most likely due to a rising incidence of pelvic inflammatory disease caused by Chlamydia trachomatis infection and the increased use of assisted reproductive techniques (Farquhar 2005, Walker 2007).

\section{Current approaches for diagnosing tubal ectopic pregnancy}

In general, the majority of patients presenting with pain or bleeding in early pregnancy have an ultrasound scan to ascertain the viability of the pregnancy and if possible the location of the gestational sac (Gracia \& Barnhart 2001). If the ultrasound proves inconclusive, a serum $\beta$-human chorionic gonadotrophin ( $\beta$-hCG) level is ascertained. The diagnosis of an ectopic pregnancy is then based on the combined sonographic findings and serum $\beta$-hCG measurements. However, it is difficult to distinguish between an ectopic pregnancy, spontaneous abortion and early ongoing intrauterine pregnancy using a single $\beta$-hCG measurement therefore repeated $\beta$-hCG measurements are taken (Gracia \& Barnhart 2001). Generally, a doubling of serum $\beta$-hCG concentrations over $48 \mathrm{~h}$ is classed as a normal rise and is therefore suggestive of viable intrauterine pregnancy (Lenton et al. 1982). If the rise is abnormal or $\beta$-hCG concentrations are static, then an ectopic pregnancevent more likely. A tubal ectopic pregnancy can then be inferred by repeated $\beta$-hCG measurements or confirmed by endometrial curettage or a more invasive laparoscopy.

\section{Difficulties diagnosing tubal ectopic pregnancy}

A tubal ectopic pregnancy can be difficult to diagnose at an early stage as nearly a third of all cases do not exhibit clinical signs and $9 \%$ have no symptoms prior to rupture (Tay et al. 2000). In addition, when a woman presents with a suspected pregnancy, in up to half the cases the diagnosis is not made on the basis of the initial consultation, scan and $\beta$-hCG estimation despite the improvement in the resolution of ultrasonography (Duncan et al. 1995, Robson \& O'Shea 1996, Munro et al. 2008). The requirement for serial $\beta$-hCG 
assessment involves multiple clinic attendances and there are ongoing difficulties in separating failing early intrauterine pregnancies from tubal ectopic pregnancies. The diagnosis of tubal ectopic pregnancy is therefore often time-consuming and costly, both psychologically to the patient and financially to health services (C) Wedderburn, P Warner, WC Duncan, B Graham \& AW Horne, unpublished observations). Consequently, a serum biomarker (Atkinson et al. 2001) of tubal implantation, which could accurately identify an ectopic pregnancy at first presentation, would be a major clinical advance (Cabar et al. 2008). A serum biomarker has been defined by the Biomarkers Definitions Working Group as 'a characteristic that is objectively measured and evaluated as an indicator of normal biological processes, pathogenic processes, or pharmacologic responses to a therapeutic intervention' (Atkinson et al. 2001). As there are no suitable animal models of tubal ectopic pregnancy, research into putative biomarkers is carried out in women. In most studies, serum concentrations of a putative biomarker are retrospectively measured in cohorts of women with a diagnosis of tubal ectopic pregnancy, ongoing intrauterine pregnancy and spontaneous abortion. This paradigm introduces major problems with interpretation of biomarker utility as the numbers are small, there are gestational differences, the samples are often collected from more than just the cohort of women in whom the diagnosis is difficult and large prospective studies are rare. However, in the pre-genomic era, a logical approach to biomarker identification has resulted in several candidate biomarkers of varying potential. These markers follow several themes (Fig. 1 and Tables 1-5) and it is likely that these themes can inform novel biomarker identification and serum diagnostic strategies in the post-genomic era.

\section{Markers of abnormal embryo/trophoblast growth}

The first theme and indeed the primary current investigative strategy for the diagnosis of tubal ectopic pregnancy are focused on molecules secreted from the conceptus (Table 1). It is likely that pregnancy implanted in the tubal environment will have abnormal growth kinetics that can be reflected in disordered measurable trophoblast function. This is characterised by the abnormal dynamics of serum $\beta$-hCG concentrations in ectopic pregnancy.

\section{Human chorionic gonadotrophin}

Serum measurement of the $\beta$-subunit of hCG is currently the only biomarker that is routinely used clinically to aid the diagnosis of ectopic pregnancy. It has been studied

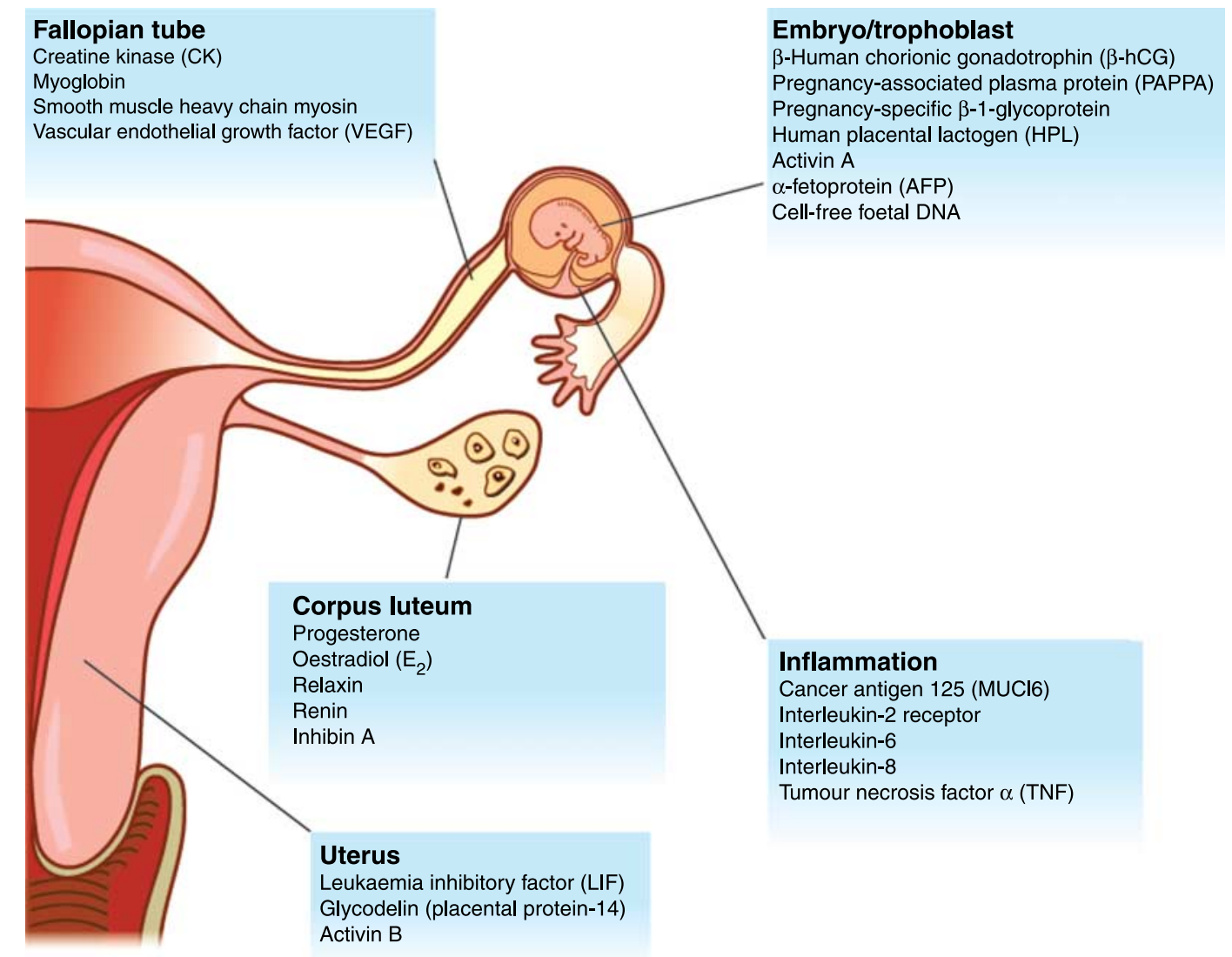

Figure 1 Serum biomarker themes. 
Table 1 Markers of abnormal embryo/trophoblast growth.

\begin{tabular}{|c|c|c|c|}
\hline Biomarker & Description & Utility as biomarker & References \\
\hline $\begin{array}{l}\beta \text {-Human chorionic } \\
\text { gonadotrophin } \\
(\beta-h C G)\end{array}$ & $\begin{array}{l}\text { Hormone produced by } \\
\text { trophoblast that maintains the } \\
\text { corpus luteum }\end{array}$ & $\begin{array}{l}\text { Serial measurements used } \\
\text { currently in clinical practice }\end{array}$ & $\begin{array}{l}\text { Seppala \& Purhonen (1987), Riss et al. (1989), } \\
\text { Garcia et al. (1990), Guillaume et al. (1990), } \\
\text { Witt et al. (1990), Mantzavinos et al. (1991), } \\
\text { Grosskinsky et al. (1993), Kuscu et al. (1993), } \\
\text { Cacciatore et al. (1994), Daily et al. (1994), } \\
\text { Korhonen et al. (1996), O'Leary et al. (1996), } \\
\text { Mol et al. (1997), Marill et al. (1999), } \\
\text { Condous et al. (2004), Mueller et al. (2004) and } \\
\text { Seeber et al. (2006) }\end{array}$ \\
\hline $\begin{array}{l}\text { Pregnancy-associated } \\
\text { plasma protein } \\
\text { A (PAPPA) }\end{array}$ & $\begin{array}{l}\text { Protease produced by placental } \\
\text { trophoblast }\end{array}$ & $\begin{array}{l}\text { Not useful as single predictive } \\
\text { marker of ectopic pregnancy }\end{array}$ & $\begin{array}{l}\text { Seppala \& Purhonen (1987), Sjoberg (1987), } \\
\text { Mueller et al. (2004) and Daponte et al. (2005) }\end{array}$ \\
\hline $\begin{array}{l}\text { Pregnancy-specific } \\
\beta-1 \text {-glycoprotein } \\
\text { (Schwangerschaft } \\
\text { protein, SP-1) }\end{array}$ & $\begin{array}{l}\text { Glycoprotein produced by } \\
\text { placental trophoblast }\end{array}$ & $\begin{array}{l}\text { Lower in ectopic pregnancy. } \\
\text { Potential biomarker. Need } \\
\text { more studies }\end{array}$ & $\begin{array}{l}\text { Ho \& Jones (1980), Seppala \& Purhonen (1987), } \\
\text { Tornehave et al. (1987), Witt et al. (1990), } \\
\text { Mantzavinos et al. (1991) and Mueller et al. } \\
\text { (2004) }\end{array}$ \\
\hline $\begin{array}{l}\text { Human placental } \\
\text { lactogen }(\mathrm{HPL})\end{array}$ & $\begin{array}{l}\text { Placental hormone that } \\
\text { increases } \\
\text { insulin production }\end{array}$ & $\begin{array}{l}\text { Not useful as single predictive } \\
\text { marker of ectopic pregnancy }\end{array}$ & $\begin{array}{l}\text { Kuscu et al. (1993), Mueller et al. (2004) and } \\
\text { Daponte et al. (2005) }\end{array}$ \\
\hline Activin A & $\begin{array}{l}\text { Glycoprotein of TGFB1 } \\
\text { superfamily that is produced } \\
\text { by the pregnant decidua and } \\
\text { ovary }\end{array}$ & $\begin{array}{l}\text { Lower in ectopic. } 100 \% \\
\text { sensitivity and } 100 \% \\
\text { specificity. Discounted in most } \\
\text { recent study due to much } \\
\text { lower sensitivity and } \\
\text { specificity. Need more studies }\end{array}$ & Florio et al. (2007) and Kirk et al. (2008) \\
\hline
\end{tabular}

extensively as a marker of ectopic pregnancy over the last 30 years (Rasor \& Braunstein 1977). Much of the early research suggested that serum $\beta$-hCG levels were reduced in ectopic pregnancy (Lundstrom et al. 1979, Milwidsky et al. 1980). However, the true value of $\beta$-hCG measurement in ectopic pregnancy is based on two crucial concepts. The first of these relates serum $\beta$-hCG concentrations to ultrasound findings using the concept of a 'discriminatory zone' (Kadar et al. 1981a). The 'discriminatory zone' was classified as the minimum serum $\beta$-hCG concentration at which an intrauterine gestational sac could be reliably identified on ultrasound assessment. Therefore, if the serum $\beta$-hCG concentration was above the proposed discriminatory zone and there was no sign of an intrauterine gestational sac on ultrasonography, an ectopic pregnancy could be diagnosed. The initial suggestion was that the discriminatory hCG concentration lay somewhere between 6000 and $6500 \mathrm{IU} / \mathrm{l}$ (Kadar et al. 1981a). However, as imaging technology improved this discriminatory value became lower, initially to $2000 \mathrm{IU} / \mathrm{I}$ (Mol et al. 1998a) and lower if there was ultrasound evidence of an adnexal mass or fluid in the pouch of Douglas. At present, most clinics have a 'discriminary zone' of between 1000 and $1500 \mathrm{IU} / \mathrm{l}$, which equates to just over 5 weeks gestation. However, care needs to be taken in interpreting single $\beta$-hCG values in the presence of twin gestation or spontaneous abortion. The second concept is the use of serial serum $\beta$-hCG measurements 2 days apart (Kadar et al. 1981b). Initial studies suggested that in $48 \mathrm{~h}$ the normal percentage increase in serum $\beta$-hCG should be at least $66 \%$ and that this would not be the case in ectopic pregnancy. However, $15 \%$ of normal intrauterine pregnancies showed a suboptimal increase and a strict cut-off for the diagnosis of ectopic pregnancy would lead to unnecessary laparoscopies. Subsequent studies have suggested that the minimum rise, over $48 \mathrm{~h}$, to predict normal viable intrauterine pregnancy was $53 \%$ (Barnhart et al. 2004) or even 35\% (Seeber et al. 2006) to avoid unnecessary laparoscopies (Condous et al. 2004). Most units currently use a much less conservative cut-off and frequently use multiple serial $\beta$-hCG assessments in cases that are difficult to diagnose. Despite its deficiencies, serum $\beta$-hCG concentrations combined with transvaginal ultrasonography is widely and routinely used as a biomarker of tubal ectopic pregnancy. However, the key concept of this biomarker is the role for dynamic assessment by measuring serum concentrations several days apart.

\section{Pregnancy-associated plasma protein- $A$}

Pregnancy-associated plasma protein-A (PAPPA) is another large glycoprotein that is produced by the trophoblast although it is also produced by the decidua (Lin et al. 1976). Early studies showed that the concentration of PAPPA was lower in patients with a tubal ectopic pregnancy when compared with normal intrauterine pregnancy (Bischof et al. 1983, Sinosich et al. 1985). Indeed, the serum concentration of PAPPA of ectopic pregnancy was sometimes within the 
Table 2 Markers of abnormal corpus luteum function.

\begin{tabular}{|c|c|c|c|}
\hline Biomarker & Description & Utility as biomarker & References \\
\hline Progesterone $(\mathrm{P})$ & $\begin{array}{l}\text { Sex steroid hormone produced by } \\
\text { corpus luteum and later placenta } \\
\text { that maintains endometrium } \\
\text { during pregnancy }\end{array}$ & $\begin{array}{l}\text { Cut-off values range from } \\
3.1 \text { to } 25 \mathrm{ng} / \mathrm{ml} \text {. Discounted in } \\
\text { large meta-analysis. Not } \\
\text { useful as single predictive marker } \\
\text { of ectopic pregnancy. Possibly of } \\
\text { value in combination with HCG }\end{array}$ & $\begin{array}{l}\text { Matthews et al. (1986), Yeko et al. (1987), Buck } \\
\text { et al. (1988), Riss et al. (1989), Guillaume } \\
\text { et al. (1990), Witt et al. (1990), Gelder et al. } \\
\text { (1991), Mantzavinos et al. (1991), Stovall } \\
\text { et al. (1992), Grosskinsky et al. (1993), Kuscu } \\
\text { et al. (1993), Daily et al. (1994), McCord } \\
\text { et al. (1996), O'Leary et al. (1996), Mol et al. } \\
\text { (1998b), Buckley et al. (2000), Condous et al. } \\
\text { (2004), Mueller et al. (2004), Daponte et al. } \\
\text { (2005) and Katsikis et al. (2006) }\end{array}$ \\
\hline Oestradiol $\left(E_{2}\right)$ & $\begin{array}{l}\text { Sex steroid hormone produced } \\
\text { by the ovary and corpus luteum } \\
\text { in response to hCG }\end{array}$ & $\begin{array}{l}\text { Reduced in ectopic pregnancy but } \\
\text { considerable overlap. } \\
\text { Discriminatory value not possible }\end{array}$ & $\begin{array}{l}\text { Guillaume et al. (1990), Witt et al. (1990), } \\
\text { Mantzavinos et al. (1991), Grosskinsky } \\
\text { et al. (1993) and Kuscu et al. (1993) }\end{array}$ \\
\hline Relaxin & $\begin{array}{l}\text { Peptide hormone produced by } \\
\text { corpus luteum }\end{array}$ & $\begin{array}{l}\text { Lower in ectopic pregnancy. } \\
\text { Potential biomarker. Need more } \\
\text { studies }\end{array}$ & Garcia et al. (1990) and Witt et al. (1990) \\
\hline Renin & $\begin{array}{l}\text { Enzyme involved in the regulation } \\
\text { of blood volume }\end{array}$ & $\begin{array}{l}\text { Lower in ectopic pregnancy. } \\
\text { Potential } \\
\text { biomarker. Need more studies }\end{array}$ & Meunier et al. (1991) \\
\hline Inhibin A & $\begin{array}{l}\text { Major peptide product of corpus } \\
\text { luteum regulated by hCG. Also } \\
\text { produced by trophoblast }\end{array}$ & $\begin{array}{l}\text { Lower in ectopic pregnancy. } \\
\text { Potential } \\
\text { biomarker. Need more studies }\end{array}$ & $\begin{array}{l}\text { Illingworth et al. (1996), Seifer et al. (1996), } \\
\text { D'Antona et al. (1998) and Segal et al. (2008) }\end{array}$ \\
\hline
\end{tabular}

non-pregnant range (Bischof et al. 1983). A subsequent larger study found that PAPPA was undetectable in $84.8 \%$ of samples from women $(n=102)$ with tubal ectopic pregnancy, but it was also undetectable in $55 \%$ of intrauterine spontaneous abortions (Sjoberg 1987). It seems that serum PAPPA concentrations are very low before 7 weeks of gestation and in isolation are poorly discriminative between spontaneous abortion and tubal ectopic pregnancy (Mueller et al. 2004, Daponte et al. 2005).

\section{Pregnancy-specific $\beta$-1-glycoprotein (Schwangerschaft protein)}

Another protein product of the placental syncytiotrophoblast is the Schwangerschaft protein (SP-1; Horne et al. 1976). When first measured in early pregnancy, all patients who had a subnormal serum SP-1 concentration $(n=29)$ had an abnormal outcome (tubal ectopic or abortion) and all cases $(n=19)$ with a normal outcome had an SP-1 within the normal range (Ho \& Jones 1980). However, in some cases, serum SP-1 was within the normal range $(n=10)$ and the pregnancy still had an abnormal outcome. Serum SP-1 concentrations do tend to be lower in tubal ectopic pregnancy (Tornehave et al. 1987), but again larger studies have confirmed that there is poor discrimination between tubal ectopic pregnancy $(n=32)$ and spontaneous abortion ( $n=42$; Witt et al. 1990). In tubal ectopic pregnancy, serial SP-1 measurements reached a plateau, while in ongoing pregnancy they continue to increase (Mantzavinos et al. 1991, Mueller et al. 2004) and the differences were most marked after 7 weeks of gestation.

\section{Human placental lactogen}

Human placental lactogen (HPL) is also a major placental product that can be detected during the first trimester (Handwerger \& Freemark 2000). It has a somatotrophic effect on the foetal tissues aided by enabling adequate foetal nutrient supply by altering the maternal carbohydrate and lipid metabolism (Walker et al. 1991). An initial study found that there were no differences in serum concentrations between ectopic and intrauterine pregnancies (Kuscu et al. 1993). However, a subsequent study involving a number of placental proteins showed that HPL levels were lower in those with tubal ectopic pregnancy compared with normal intrauterine pregnancy, particularly after 7 weeks of gestation (Mueller et al. 2004). Although this finding has been confirmed in a different set of patients (Daponte et al. 2005), the marked overlap in values between groups limits its utility as a clinically useful biomarker.

\section{Activin A}

Activin A is a member of the transforming growth factor$\beta$ family that is secreted from the ovary and placenta (Petraglia et al. 1987, Wen et al. 2008). However, in pregnancy, the main source of secretion is the trophoblast (Petraglia et al. 1987). Florio et al. (2007) examined the blood samples of 486 women (viable intrauterine pregnancy $(n=155)$, first-trimester spontaneous miscarriage $(n=305)$, tubal ectopic pregnancy $(n=76))$ and found that activin A levels in women with tubal ectopic pregnancy were markedly lower than those with intrauterine pregnancy and spontaneous miscarriage $(P<0.0001)$. More importantly, it performed better 
Table 3 Markers of growing pregnancy in the Fallopian tube.

\begin{tabular}{|c|c|c|c|}
\hline Biomarker & Description & Utility as biomarker & References \\
\hline $\begin{array}{l}\text { Creatine kinase } \\
\quad(\mathrm{CK})\end{array}$ & $\begin{array}{l}\text { Enzyme that is released from } \\
\text { damaged muscle cells }\end{array}$ & $\begin{array}{l}\text { Two conflicting studies from same group. } \\
\text { Conflicting data about cut-off level. } \\
\text { Higher if ruptured. Possibly useful as a } \\
\text { marker of ruptured ectopic pregnancy }\end{array}$ & $\begin{array}{l}\text { Lavie et al. (1993), Chandra \& Jain (1995), } \\
\text { Duncan et al. (1995), Paige \& Kurzel (1995), } \\
\text { Darai et al. (1996), Garcia-Velasco et al. } \\
\text { (1996), Korhonen et al. (1996), Lincoln et al. } \\
\text { (1996), Qasim et al. (1996), Vandermolen \& } \\
\text { Borzelleca (1996), Plewa et al. (1998), } \\
\text { Birkhahn et al. (2000a, 2001), Kurzel et al. } \\
\text { (2001), Develioglu et al. (2002) and } \\
\text { Soundravally et al. (2007) }\end{array}$ \\
\hline Myoglobin & $\begin{array}{l}\text { One of protein components of } \\
\text { muscle fibres }\end{array}$ & $\begin{array}{l}\text { Not useful as single predictive } \\
\text { marker of ectopic pregnancy }\end{array}$ & Birkhahn et al. (2001) \\
\hline $\begin{array}{l}\text { Smooth muscle } \\
\text { heavy-chain } \\
\text { myosin }\end{array}$ & $\begin{array}{l}\text { One of protein components of } \\
\text { muscle fibres }\end{array}$ & $\begin{array}{l}\text { Not useful as single predictive } \\
\text { marker of ectopic pregnancy }\end{array}$ & Birkhahn et al. $(2000 b, 2001)$ \\
\hline $\begin{array}{l}\text { Vascular endothelial } \\
\text { growth factor } \\
\text { (VEGF) }\end{array}$ & $\begin{array}{l}\text { Potent angiogenic factor that } \\
\text { stimulates profound } \\
\text { angiogenesis at implantation } \\
\text { site }\end{array}$ & $\begin{array}{l}\text { Discounted in largest study to date. } \\
\text { Possibly useful as single predictive } \\
\text { marker of ectopic pregnancy in selected } \\
\text { patient groups }\end{array}$ & $\begin{array}{l}\text { Daniel et al. (1999), Felemban et al. (2002), } \\
\text { Kucera-Sliutz et al. (2002), Fasouliotis et al. } \\
\text { (2004), Mueller et al. (2004) and } \\
\text { Daponte et al. (2005) }\end{array}$ \\
\hline
\end{tabular}

than a single measurement of hCG in discriminating between the different groups (Florio et al. 2007). When using activin $A$ as a single marker, the authors calculated that for their study population (tubal ectopic pregnancy prevalence $14.18 \%$ ), a tubal ectopic pregnancy could be identified with a sensitivity of $100 \%$ and specificity of $99.6 \%$ if the cut-off was $<0.37 \mathrm{ng} / \mathrm{ml}$. Disappointingly, a preliminary report of the use of activin $A$ as a single biomarker for the diagnosis of tubal ectopic pregnancy in a different population of women has been less encouraging, with a much lower specificity and sensitivity (Kirk et al. 2008). Although it is not being used in clinical practice, activin A remains a potentially important biomarker that is worthy of further study.

\section{$\alpha$-Foetoprotein and cell-free foetal DNA}

Unlike the above markers of trophoblast function, which are lower in ectopic pregnancy, it was hypothesised that some embryonic markers, which are normally maintained within the conceptus, would be released during abnormal tubal implantation. $\alpha$-Foetoprotein (AFP) is a product of both the yolk sac and the foetal liver (Jones et al. 2001) and an initial study suggested that serum AFP was elevated in tubal ectopic pregnancy (Grosskinsky et al. 1993). However, a subsequent study has not confirmed this finding (Kuscu et al. 1993) and it is known from serum screening programmes that threatened abortion can increase serum AFP in ongoing pregnancies.

Foetal DNA escaping into the maternal circulation has also been analysed with more positive results. Lazar et al. (2006) examined cell-free foetal DNA, looking at the Sry gene, in blood samples from 58 women. They identified the Sry gene in 15 women who had a tubal ectopic pregnancy and 14 women with an intrauterine pregnancy, and its concentration was significantly higher in those with a tubal ectopic pregnancy $(P<0.001)$.
Using a cut-off of $>80 \mathrm{GE} / \mathrm{ml}$, this test was able to differentiate a tubal ectopic from an intrauterine pregnancy with sensitivity of $84 \%$, a specificity of $76 \%$, a positive predictive value (PPV) of $83 \%$ and a negative predictive value (NPV) of $83 \%$ (Lazar et al. 2006). This technology at present is lengthy and complex and cannot be used when the conceptus is female, so its utility as a clinically useful serum biomarker is very limited.

\section{Markers of abnormal corpus luteum function}

The second theme is the assessment of luteal function by measuring secreted ovarian products (Table 2). Ongoing function of the corpus luteum is fundamental to maternal recognition of pregnancy and the maintenance of early pregnancy. In women, the corpus luteum is rescued from luteolysis by hCG from the implanting blastocyst. Luteal function in early pregnancy is absolutely dependent on logarithmically increasing serum hCG concentrations, and in the absence of normal hCG kinetics, it is suboptimal. It was therefore evident that a single measurement of a luteal product may give a clearer picture of recent hCG dynamics, which are suboptimal in ectopic pregnancy, than a single measurement of hCG.

\section{Steroids from the corpus luteum}

\section{Progesterone}

The most obvious luteal cell product is progesterone and there has been much research into its utility as a biomarker of ectopic pregnancy or a pregnancy of unknown location. It was initially reported, in a small cohort, that all women with tubal ectopic pregnancies $(n=29)$ had a serum progesterone measurement of $<15 \mathrm{ng} / \mathrm{ml}$ and this was lower than women $(n=20)$ with a viable intrauterine pregnancy (Matthews et al. 1986). 
Table 4 Markers of inflammation and peritoneal irritation.

\begin{tabular}{|c|c|c|c|}
\hline Biomarker & Description & Utility as biomarker & References \\
\hline $\begin{array}{l}\text { Cancer antigen-125 } \\
\text { (MUC16) }\end{array}$ & $\begin{array}{l}\text { Cell-surface antigen primarily tumour } \\
\text { marker. Lines female genital tract } \\
\text { and pregnant deciduas }\end{array}$ & $\begin{array}{l}\text { Higher in miscarriage. Unable } \\
\text { to differentiate between } \\
\text { ectopic and viable } \\
\text { intrauterine pregnancy }\end{array}$ & $\begin{array}{l}\text { Halila et al. (1986), Brumsted } \\
\text { et al. (1990), Witt et al. } \\
\text { (1990), Sadovsky et al. } \\
\text { (1991), Kuscu et al. (1993) } \\
\text { and Katsikis et al. (2006) }\end{array}$ \\
\hline $\begin{array}{l}\text { Interleukin-2 } \\
\text { receptors }\end{array}$ & $\begin{array}{l}\text { Protein expressed on surface of } \\
\text { T-lymphocytes }\end{array}$ & $\begin{array}{l}\text { Not useful as single predictive } \\
\text { marker of ectopic pregnancy }\end{array}$ & Soriano et al. (2003) \\
\hline Interleukin-6 & $\begin{array}{l}\text { Pro-inflammatory cytokine } \\
\text { secreted by T-lymphocytes }\end{array}$ & $\begin{array}{l}\text { Potentially useful. Higher in } \\
\text { ectopic compared with } \\
\text { viable and non-viable } \\
\text { pregnancies. Need more } \\
\text { studies }\end{array}$ & \\
\hline Interleukin-8 & $\begin{array}{l}\text { Chemokine produced by } \\
\text { macrophages }\end{array}$ & & \\
\hline $\begin{array}{l}\text { Tumour necrosis } \\
\text { factor (TNF) }\end{array}$ & $\begin{array}{l}\text { Cytokine involved in } \\
\text { regulation of the immune } \\
\text { response }\end{array}$ & & \\
\hline
\end{tabular}

A follow-up study, using this cut-off, reported that all ectopic pregnancies were identified at the patient's first visit to the emergency department and that none were mistaken for viable intrauterine pregnancies (Yeko et al. 1987). A larger study around the same time also found serum progesterone measurement to be a valuable diagnostic test for tubal ectopic pregnancy (Buck et al. 1988). Using a cut-off of $20 \mathrm{ng} / \mathrm{ml}$, women with an ectopic pregnancy $(n=89)$, when compared with spontaneous abortion $(n=27)$ or ongoing intrauterine pregnancy $(n=77)$, could be predicted with a sensitivity of $92 \%$, a specificity of $84 \%$, a PPV of $90 \%$ and NPV of 87\% (Buck et al. 1988). However, not all studies had the same success. Riss et al. (1989) were only able to diagnose a tubal ectopic pregnancy, using the cut-off of $15 \mathrm{ng} / \mathrm{ml}$, with a sensitivity of $93 \%$, specificity of $47 \%$ and perhaps most crucially a PPV of only $30 \%$. They concluded that tubal ectopic pregnancy could not be identified on the basis of serum progesterone measurement alone. Subsequent studies have reported mixed results. Guillaume et al. (1990) investigated a larger population of 205 women with tubal ectopic pregnancy $(n=100)$, viable intrauterine pregnancy $(n=69)$ and threatened abortion $(n=36)$ and found that all but one of the women with a tubal ectopic pregnancy had serum P levels $<23 \mathrm{ng} / \mathrm{ml}$ and this had a sensitivity of $99 \%$ and a specificity of $100 \%$. However, serum progesterone levels are significantly lower in both tubal ectopic pregnancies $(n=32 ; P<0.001)$ and spontaneous abortions $(P<0.001)$ than viable intrauterine pregnancies (Witt et al. 1990). Crucially, there was no significant difference in serum progesterone concentrations in women with an ectopic pregnancy when compared with those who had a spontaneous abortion and this reduced the predictive value of progesterone. Subsequent studies have highlighted the considerable overlap in progesterone concentrations between diagnostic groups. In one study, $31 \%$ of viable intrauterine pregnancies, $23 \%$ of abnormal intrauterine pregnancies and $52 \%$ of tubal ectopic pregnancies had a serum progesterone concentration between 10 and $20 \mathrm{ng} / \mathrm{ml}$ (Gelder et al. 1991). Many subsequent studies into the utility of progesterone as a biomarker for tubal ectopic pregnancy had similar results. Serum progesterone levels are significantly lower in tubal ectopic pregnancy but that they are not discriminative enough to be diagnostic in isolation (Mantzavinos et al. 1991, Grosskinsky et al. 1993, Kuscu et al. 1993, Daily et al. 1994, Ledger et al. 1994, McCord et al. 1996, O'Leary et al. 1996, Mol et al. 1998b, Buckley et al. 2000, Condous et al. 2004, Mueller et al. 2004). However, the concept that progesterone can be a marker of serial hCG dynamics

Table 5 Uterine markers of normal implantation.

\begin{tabular}{|c|c|c|c|c|}
\hline Category & Biomarker & Description & Utility as biomarker & References \\
\hline \multirow[t]{3}{*}{ Uterus } & $\begin{array}{l}\text { Leukaemia inhibitory } \\
\text { factor (LIF) }\end{array}$ & $\begin{array}{l}\text { Glycopeptide cytokine, member } \\
\text { of the interleukin- } 6 \text { family }\end{array}$ & $\begin{array}{l}\text { Not useful as single predictive } \\
\text { marker of ectopic pregnancy }\end{array}$ & $\begin{array}{l}\text { Wegner \& Mershon (2001) } \\
\text { and Daponte et al. (2005) }\end{array}$ \\
\hline & $\begin{array}{l}\text { Glycodelin (placental } \\
\text { protein-14) }\end{array}$ & $\begin{array}{l}\text { Major secretory product of } \\
\text { endometrium }\end{array}$ & $\begin{array}{l}\text { Findings of previous studies } \\
\text { not replicated in the biggest } \\
\text { and most recent study. Not } \\
\text { useful as single predictive } \\
\text { marker of ectopic pregnancy }\end{array}$ & $\begin{array}{l}\text { Pedersen et al. (1991), Ruge } \\
\text { et al. (1992), Stabile et al. } \\
\text { (1994), Foth \& Romer } \\
\text { (2003) and Daponte } \\
\text { et al. (2005) }\end{array}$ \\
\hline & Activin B & $\begin{array}{l}\text { Glycoprotein of TGFB } 1 \text { superfamily } \\
\text { that is produced by pregnant } \\
\text { decidua and enhances FSH } \\
\text { secretion }\end{array}$ & $\begin{array}{l}\text { Lower in ectopic pregnancy } \\
\text { Potential biomarker. Need } \\
\text { more studies }\end{array}$ & Horne et al. (2008) \\
\hline
\end{tabular}


still has some merit. When the value of a single serum progesterone measurement $(<25 \mathrm{ng} / \mathrm{ml})$ is compared with serial hCG measurements $(n=402)$, it was significantly more sensitive $(P<0.05)$ in the diagnosis of ectopic pregnancy than two hCG measurements of $48 \mathrm{~h}$ apart (Stovall et al. 1992). Some centres have added progesterone assessment to the standard hCG/ultrasound diagnostic protocol; however, its value as a useful discriminatory tool in practice has been questioned (Daponte et al. 2005, Katsikis et al. 2006). It is clear that progesterone concentrations are lower in tubal ectopic pregnancy and this probably does reflect hCG dynamics. However, the poor discriminatory capabilities of a single serum progesterone measurement mean that its value as a serum biomarker does not support its routine use in clinical practice.

\section{Oestradiol}

The corpus luteum of women also secretes oestradiol $\left(E_{2}\right)$ in response to hCG and again could function as a luteal marker of pregnancy dynamics. A preliminary study in 205 women confirmed that all of the ectopic pregnancies $(n=100)$ had an $\mathrm{E}_{2}$ level $<650 \mathrm{pg} / \mathrm{ml}$ and all but one of the intrauterine pregnancies had a value $>650 \mathrm{pg} / \mathrm{ml}$ (Guillaume et al. 1990) giving a sensitivity of $100 \%$ and specificity of $99 \%$. However, again there was no difference in serum $E_{2}$ when women with tubal ectopic pregnancy were compared with those with nonviable intrauterine pregnancies (Witt et al. 1990). There are differences in serial serum $E_{2}$ concentrations in tubal ectopic pregnancy when compared with viable intrauterine pregnancies measured up to 11 weeks of gestation (Mantzavinos et al. 1991). While $\mathrm{E}_{2}$ concentrations rose continuously in viable pregnancies, they were reduced in tubal ectopic pregnancy and the values plateaued after the sixth week and declined after the eighth week of gestation. However, like progesterone assessment, $\mathrm{E}_{2}$ concentrations overlapped between different diagnostic groups (Mantzavinos et al. 1991, Grosskinsky et al. 1993, Kuscu et al. 1993) and the considerable overlap meant that identifying a discriminatory cut-off value was not possible and $\mathrm{E}_{2}$ assessment as a biomarker has not entered clinical practice.

\section{Peptides from the corpus luteum}

\section{Relaxin and renin}

Relaxin is a well-recognised peptide hormone produced by the corpus luteum during pregnancy (Weiss et al. 1976). It has been shown to be elevated shortly after conception and remain steady until the 15th week of gestation (Szlachter et al. 1982). Preliminary assessment showed that serum relaxin concentrations in patients with a tubal ectopic pregnancy $(n=9)$ were significantly lower than that in those $(n=13)$ with a viable intrauterine pregnancy (Garcia et al. 1990).
However, 67 out of 74 (91\%) patients with either a spontaneous miscarriage or tubal ectopic pregnancy had low concentrations of relaxin and as such it too was poorly discriminatory as a biomarker of ectopic pregnancy (Witt et al. 1990). The ovaries are now known to be a source of extrarenal renin and its production has been shown to rise when ovulation is followed by pregnancy (Sealey et al. 1987). It has been reported that active renin was significantly decreased in women with an ectopic pregnancy when compared with those with an ongoing intrauterine pregnancy or spontaneous miscarriage (Meunier et al. 1991). However, although a low active renin $(<30 \mathrm{pg} / \mathrm{ml})$ in combination with low hCG could predict a tubal ectopic pregnancy, the specificity of $76 \%$ and PPV of $75 \%$ suggested little clinical utility and further assessment has been limited (Meunier et al. 1991).

\section{Inhibin A}

Inhibin $A$ is a major peptide product of the corpus luteum whose secretion is regulated by hCG (Illingworth et al. 1996). Although inhibin A is produced by the trophoblast, the corpus luteum is the major source of inhibin A in early pregnancy (Treetampinich et al. 2000). Serum dimeric inhibin $A$ and pro- $\alpha-C$ inhibin were lower in women with tubal ectopic pregnancies than ongoing intrauterine pregnancies (Illingworth et al. 1996, Seifer et al. 1996) and fell more precipitously than hCG after treatment for ectopic pregnancy due to its shorter half-life (D'Antona et al. 1998). A recent prospective study has suggested that inhibin A was lower in ectopic pregnancies $(n=17)$ than both ongoing $(P<0.0002)$ and failing intrauterine $(P<0.0002)$ pregnancies and it may be a better marker to differentiate between a failing pregnancy and tubal ectopic pregnancy than hCG (Segal et al. 2008). It thus is an attractive potential biomarker and more studies are required to assess its utility in clinical practice.

\section{Markers of growing pregnancy in the Fallopian tube}

The circular layer of smooth muscle that surrounds the Fallopian tube can be disrupted by a growing ectopic pregnancy. Indeed, the integrity of the tubal musculature is particularly disrupted during tubal rupture. It is clear that the damaged Fallopian tube will release potentially measurable compounds into the circulation and these could be used as biomarkers of tubal implantation. Markers of muscle damage have been investigated as potential markers of tubal ectopic pregnancy (Table 3).

\section{Creatine kinase}

Creatine kinase (CK) is an enzyme that is released when muscle becomes damaged and is currently used as a diagnostic biomarker for myocardial infarction (Costa et al. 2008). The first study of CK as a marker of Fallopian 
tube damage produced some encouraging results (Lavie et al. 1993). Serum CK concentrations were significantly higher in those with tubal pregnancy $(n=17)$ as opposed to those with missed abortion $(n=17)$ or normal pregnancy $(n=17)$. In this study, there was no overlap between the groups and all women with a tubal ectopic pregnancy had a CK level $>45 \mathrm{IU} / \mathrm{l}$. As well as being higher than ongoing pregnancies $(n=20)$ or missed abortions $(n=20), C K$ in tubal ectopic pregnancies $(n=20)$ was also higher $(P<0.0001)$ than that in women with acute appendicitis $(n=10)$ or pelvic inflammatory disease $(n=20$; Chandra \& Jain 1995). However, when used as a marker in an unselected population, although serum CK was significantly higher in tubal ectopic $(P<0.001)$ compared with intrauterine pregnancy (ongoing pregnancy, complete abortion and incomplete abortion), there was considerable overlap in the values and with a cut-off of $45 \mathrm{IU} / \mathrm{l}$ had a sensitivity of $57 \%$ and specificity of $67 \%$ (Duncan et al. 1995). Some subsequent studies have shown no significant increases in serum CK concentrations in ectopic pregnancy (Darai et al. 1996, Garcia-Velasco et al. 1996, Korhonen et al. 1996, Lincoln et al. 1996, Qasim et al. 1996, Vandermolen \& Borzelleca 1996, Plewa et al. 1998). However, others suggest that there are indeed increases in serum CK in tubal ectopic pregnancy (Birkhahn et al. 2000a) although it did not work well as a screening tool in a high-risk population (Birkhahn et al. 2001, Kurzel et al. 2001). The differences in these studies may be because serum CK concentrations may actually be a marker of potential tubal rupture rather than tubal ectopic pregnancy per se (Develioglu et al. 2002). When a study population of women with normal intrauterine pregnancies, unruptured ectopic pregnancies and ruptured ectopic pregnancies was examined, serum CK concentrations were significantly higher in the patients with ruptured tubal ectopic pregnancy compared with unruptured tubal ectopic pregnancy $(P=0.003)$ and normal intrauterine pregnancy $(P<0.0001$; Develioglu et al. 2002). Indeed, CK concentrations appeared to be affected by tubal location as they were significantly higher in those with isthmic as opposed to ampullary pregnancies. This observation has been confirmed in a more recent study where CK levels were also higher in isthmic tubal ectopic pregnancies and ruptured ectopic pregnancies (Soundravally et al. 2007). It is likely that as a tubal ectopic pregnancy grows and progresses towards rupture, then serum CK concentrations are increased. However, despite the initial excitement, this has not proven to be a clinically useful discriminator.

\section{Myoglobin and smooth muscle heavy-chain myosin}

Other markers of muscle damage have also been investigated as potential biomarkers of tubal damage in ectopic pregnancy. Myoglobin is a small intracellular protein component of muscle fibres (Wodzig et al. 1997), which is released as a result of striated muscle degradation. There was no correlation between its serum concentration and pregnancy location (Birkhahn et al. 2001). This may be because it is debatable whether it is expressed in smooth muscle fibres (Enoki \& Morimoto 2000) and it has a very short circulatory halflife (Klocke et al. 1982). It does not appear to have any validity as a candidate biomarker of ectopic pregnancy. Neither does myoglobin and smooth muscle heavy-chain myosin (MYH11), another marker of muscle destruction (Katoh et al. 1995). Although this marker is significantly elevated in women with tubal ectopic pregnancies (Birkhahn et al. 2000b), the wide spread of values in each diagnostic group made its utility as a marker suspect. A larger study confirmed that it was higher in ectopic pregnancy but it was not discriminatory enough for clinical use with a PPV of $22 \%$ and an NPV of $91 \%$ (Birkhahn et al. 2001).

\section{Vascular endothelial growth factor}

Vascular endothelial growth factor (VEGF) is a potent angiogenic factor that plays a key role in vascular growth, permeability and remodelling (Neufeld et al. 1999). It has a major role in the regulation of angiogenesis in the corpus luteum (Fraser \& Duncan 2005) and the endometrium (Fraser et al. 2008). It also has a vital role during implantation and placentation and its expression is stimulated by tissue hypoxia (Ladoux \& Frelin 1993). It was therefore hypothesised that implantation in the unfavourable Fallopian tube would be associated with increased tissue hypoxia and that, despite a role in endometrial and luteal development, serum VEGF would be increased in tubal ectopic pregnancy (Daniel et al. 1999). Indeed, serum VEGF concentrations were significantly higher in tubal ectopic pregnancy compared with normal intrauterine pregnancy although there was only borderline significance between tubal ectopic pregnancy and failing intrauterine pregnancy (Daniel et al. 1999). In this study, serum VEGF of $>200 \mathrm{pg} / \mathrm{ml}$ could discriminate a tubal ectopic pregnancy from an intrauterine pregnancy with a specificity of $90 \%$ and a PPV of $86 \%$. Using the same cut-off, Felemban et al. (2002) reported that all 15 women they tested with an intrauterine pregnancy had a serum VEGF of $<200 \mathrm{pg} / \mathrm{ml}$ and they were able to distinguish a tubal ectopic pregnancy with a sensitivity of $88 \%$, specificity of $100 \%$ and PPV of $100 \%$. Another study at the same time $(n=84)$, however, failed to find statistical differences between serum VEGF concentrations between women with a tubal ectopic pregnancy and those with a failing intrauterine pregnancy (Kucera-Sliutz et al. 2002) and the discrimination was poor with a sensitivity of $56 \%$, specificity of $51 \%$ and PPV of $53 \%$. However, when normal intrauterine pregnancy is compared with tubal ectopic pregnancy, serum VEGF correlations do appear to be consistently 
elevated (Mueller et al. 2004). That said, although no tubal ectopic pregnancy had a serum VEGF $<5 \mathrm{pg} / \mathrm{ml}$, the overall values were widely spread over a range from 11.1 to $1056 \mathrm{pg} / \mathrm{ml}$ (Mueller et al. 2004). Although serum VEGF concentrations are increased after ovarian stimulation in an IVF cycle (Licht et al. 2001), they are still higher in tubal ectopic pregnancy than intrauterine pregnancy in this cohort of women (Fasouliotis et al. 2004). Using an increased cut-off of $700 \mathrm{pg} / \mathrm{ml}$, serum VEGF was able to distinguish a normal intrauterine pregnancy from a tubal ectopic pregnancy with a PPV of $70 \%$ and an abnormal intrauterine pregnancy from a tubal ectopic pregnancy with a PPV of $88 \%$ (Fasouliotis et al. 2004). Indeed, the ability to distinguish between an ectopic pregnancy and a failing intrauterine pregnancy may be better than originally thought (Daponte et al. 2005). In this study, serum VEGF could discriminate between tubal ectopic pregnancy $(n=27)$ and abnormal intrauterine pregnancy $(n=21)$ at a median gestational age of 7.15 weeks with a sensitivity of $78 \%$ and specificity of $100 \%$. Although VEGF is a promising biomarker, it has still to be studied in large prospective studies and its clinical utility has yet to be established.

\section{Markers of inflammation and peritoneal irritation}

It is clear that tubal ectopic pregnancy is associated with peritoneal irritation and indeed this irritation can cause the pelvic pain leading to presentation. As such, markers of peritoneal irritation such as MUC16 and inflammation such as various cytokines have been investigated as possible biomarkers of tubal ectopic pregnancy (Table 4).

\section{Cancer antigen 125}

Cancer antigen 125 (MUC16) is typically associated as a biomarker of ovarian carcinoma (Canney et al. 1984). However, it is raised in benign conditions with peritoneal involvement such as endometriosis and uterine fibroids. It is also elevated during early pregnancy and therefore may be more of a marker than peritoneal irritation or inflammation. Indeed, some ectopic pregnancies $(n=15)$ were included in an ovarian carcinoma screening study and all had low concentrations of serum MUC16 (Halila et al. 1986). When serum concentrations in early pregnancy were investigated, MUC16 increases in normal early pregnancy (Brumsted et al. 1990) and subjects with tubal ectopic pregnancy had a wide range of MUC16 concentrations, but overall they were lower than those seen in normal pregnancy (Brumsted et al. 1990, Witt et al. 1990). Further evidence, however, suggested that serum MUC16 concentrations were increased, rather than reduced, in tubal ectopic pregnancy (Sadovsky et al. 1991) and another study suggested no differences between diagnostic groups (Kuscu et al. 1993).
At present, the conflicting studies suggest that serum MUC16 is not a biomarker for tubal ectopic pregnancy. The differences in these studies may reflect the proportion of patients with spontaneous abortion included as it seems that this group do have significantly elevated concentrations of serum MUC16 per se (Katsikis et al. 2006).

\section{Interleukin-2 receptors, interleukin-6, interleukin-8 and tumour necrosis factor}

The possible predictive potential of cytokines, which are primarily associated with inflammation (interleukin-2 receptors (IL2R), interleukin-6 (IL6), IL8 and tumour necrosis factor (TNF)), in the diagnosis of tubal ectopic pregnancy has been assessed (Soriano et al. 2003). When the sera of 72 women (33 with viable intrauterine pregnancy, 22 with miscarriage and 17 with tubal ectopic pregnancy) were examined, there was no difference in the serum concentration of IL2R between the three groups. However, the concentration of IL6, IL8 and TNF were significantly higher in tubal ectopic pregnancy when compared with those with a viable intrauterine pregnancy $(P=0.03, P=0.0001, P=0.0007$ respectively) and miscarriage ( $P=0.05, P=0.0001, P=0.002$; Soriano et al. 2003). In addition, serum levels of IL6, IL8 and TNF did not differ between those with viable intrauterine pregnancy and those who miscarried. These positive findings, however, still need to be replicated prospectively in a much larger cohort of women.

\section{Uterine markers of normal implantation}

The normal interaction between the pregnancy and the uterine decidua can result in the detection of uterine products in the maternal circulation. It can be anticipated that this normal secretion may be disrupted in the presence of tubal implantation and that uterine products may have a facility as a biomarker for tubal ectopic pregnancy (Table 5).

\section{Leukaemia inhibitory factor}

One such uterine marker is leukaemia inhibitory factor (LIF). Although LIF is a cytokine of the IL6 family with a role in inflammation, it has been shown to have a key function in implantation (Senturk \& Arici 1998). It was initially hypothesised that its involvement in inflammation be more important than its expression during normal implantation and that serum LIF would be elevated in tubal ectopic pregnancy (Wegner \& Mershon 2001). However, that study suggested that women with a tubal ectopic pregnancy $(n=11)$ had the lowest mean serum LIF concentrations. Nevertheless, there was considerable overlap between the values in ectopic pregnancy and normal and failing intrauterine pregnancies and the test had a $73 \%$ sensitivity and a $72 \%$ 
specificity for the diagnosis of ectopic pregnancy (Wegner \& Mershon 2001). However, a larger study failed to find any differences in serum LIF concentrations between the patients with an ectopic pregnancy and those with an abnormal intrauterine pregnancy (Daponte et al. 2005).

\section{Glycodelin (placental protein-14)}

Glycodelin, also known as placental protein-14 (PAEP), is a major secretory product of the endometrium and decidua (Ruge et al. 1992). In normal ovulatory cycles, its production increases as the secretory changes in the endometrial tissue progress (Julkunen et al. 1986). In addition, serum PAEP concentrations increase gradually during early first-trimester pregnancy until weeks 8-10 of gestation and then decline (Ruge et al. 1992). Pedersen et al. (1991) found, in a small cohort of 20 women, that women with ectopic pregnancy had significantly lower serum concentrations of PAEP. This was confirmed in a larger cohort of women with a tubal ectopic pregnancy ( $n=59$; Ruge et al. 1992). A comparison of serum PAEP concentrations in women with spontaneous abortion $(n=32)$ and ectopic pregnancy $(n=26)$ found that $81 \%$ of women with spontaneous abortion had PAEP serum concentration levels within the normal range while $81 \%$ of women diagnosed with an ectopic pregnancy had PAEP levels below the fifth percentile of the normal range (Stabile et al. 1994). In addition, the lower concentrations of serum glycodelin in ectopic pregnancy was not dependent on tubal status as this difference was maintained in patients with an unruptured tube, a ruptured tube or a tubal miscarriage (Foth \& Romer 2003). Although glycodelin seems to be a potentially useful biomarker worthy of further study, it is notable that it was not discriminatory when used in a large multi-biomarker study (Daponte et al. 2005).

\section{The identification of uterine markers using a genomic approach}

The strategies highlighted above have investigated secreted molecules whose role in normal pregnancy development has been reported and therefore a logical approach has suggested them as possible candidate biomarkers that are altered in tubal ectopic pregnancy. We sought to identify novel decidual markers of intrauterine and ectopic implantation using array technology. We used gene profiling of endometrium from gestation-matched women with viable or nonviable intrauterine pregnancies and compared the profiles with those of women with tubal ectopic pregnancies (Horne et al. 2008). This approach revealed that activin $B$ is secreted by the decidua and its expression is increased during decidualisation.
In addition, women with tubal ectopic pregnancy had a less decidualised endometrium and lower concentrations of serum activin B ( $P<0.01$; Horne et al. 2008). Although this needs to be repeated in a different population of patients in a larger prospective study, it has highlighted that in the post-genomic era an array approach can highlight unexpected potential biomarkers for further evaluation.

\section{Discussion}

Currently, there is sadly no stand-alone diagnostic biomarker for tubal ectopic pregnancy that has been adequately tested and yields accurate results. However, in general, it seems that markers of normal trophoblast and decidual function are lower in tubal ectopic pregnancy as are markers of normal luteal function. By contrast, serum markers of tubal damage, tubal implantation or peritoneal inflammation tend to be increased in women with tubal ectopic pregnancy. Certain serum biomarkers have been shown initially to be of discriminatory value, but subsequent studies have then found them to be of limited use (e.g. PAEP). A number of biomarkers (e.g. $E_{2}$, PAPPA, MUC16) can distinguish a tubal ectopic from a viable intrauterine pregnancy but are unable to distinguish the former from a non-viable failing intrauterine pregnancy. Other markers (e.g. VEGF, $\mathrm{CK}$, progesterone) have been studied extensively in relation to ectopic pregnancy, but the results have not been consistently convincing enough for them to enter routine clinical practice. The considerable difference in the results of these studies is likely due to limitations in their study design and the nature of the biomarkers themselves. Often the actual cohort that was studied was very small and the prevalence of tubal ectopic pregnancy within the study population is not constant or clinically relevant. The authors also frequently found it difficult to match the subjects for gestational age. This was partly due to the fact that often they were looking retrospectively at patients who attended their emergency department and also due to the general nature of a tubal ectopic pregnancy, which is typically difficult to age. Furthermore, the majority of the studies did not take into account the precise location of the tubal ectopic pregnancy. Develioglu et al. (2002) found that there was a significant difference in the level of CK between ampullary and isthmic ectopic implantations, thus the exclusion of this variable in other studies may also have affected their results. Furthermore, the serum biomarkers can also limit their own use, as often they do not follow a steady pattern (increase or decrease) over a normal gestation. This means that if the subjects are not matched for gestational age large differences can be seen within the same group. An ideal marker would be one that remained constant from an early stage of pregnancy, but in practice this is yet to be found. The accuracy of serum assays has also improved over the last decades and this 
may partially account for why many biomarkers have gradually been found to be of limited use. Differing results between the studies may also be the artefact of different methods of biomarker identification and the reagent used to detect them.

As a result of the limited success of single serum biomarker measurement, many researchers have started to investigate the possibility of using multiple serum biomarker analysis in order to diagnose tubal ectopic pregnancy. O'Leary et al. (1996) examined progesterone and $\beta$-hCG levels and found, in preliminary studies, that a plasma $\beta$-hCG $<3000 \mathrm{IU} / \mathrm{l}$ and a plasma progesterone $<40 \mathrm{nmol} / \mathrm{l}$ could predict a tubal ectopic pregnancy with a sensitivity of $88 \%$ and specificity of $82 \%$. A single serum progesterone measurement may be useful in identifying an abnormal pregnancy (although not specifically a tubal ectopic) in women with a serum $\beta$-hCG measurement $<1000 \mathrm{IU} / \mathrm{I}$ with a sensitivity of $94 \%$ and specificity of $100 \%$ (Dart et al. 1998). A number of other multiple serum biomarker studies have focused on the development of an equation that could accurately diagnose a tubal ectopic pregnancy by combining the assay results of several biomarkers. An equation that amalgamated the serum level of both MUC16 and $E_{2}$ predicted the probability of both miscarriage and 21 out of 29 cases $(72 \%)$ of tubal ectopic pregnancy (Witt et al. 1990). A triple marker analysis (Mueller et al. 2004) had a high sensitivity and specificity in diagnosing tubal ectopic pregnancy (97.7 and $92.4 \%$ respectively), but again showed limitations in its utility with unexpected results in some women. A logical approach to multiple biomarker testing is to combine possible independent markers from the groups described above. Current information would support further assessment of hCG or activin A as a trophoblast marker, progesterone or inhibin $\mathrm{A}$ as a luteal marker, VEGF or TNF as a tubal marker and activin $\mathrm{B}$ or glycodelin as a uterine marker in various combinations. For the future, an ideal serum biomarker would be one or more that could be accurately and quickly assayed, preferably in an emergency department setting. However, it would also have to be an inexpensive measure in order to have true value clinically. Fundamentally, the question of whether a serum biomarker exists that can accurately and specifically detect a tubal ectopic pregnancy is still unanswered. Furthermore, with the advent of better imaging techniques, a serum biomarker may be superseded by ultrasound-related technology.

\section{Search strategy and selection criteria}

The following databases were searched: PubMed, MEDLINE and the Cochrane Library using the search term 'ectopic pregnancy' alone and in combination with 'diagnosis', 'screening', 'biomarkers', 'hormones', 'hCG', 'progesterone', 'oestradiol', 'activin', 'VEGF' and ' $C K^{\prime}$ '. Reference lists of articles identified by this search were then used to look for further studies and related articles. Only articles published in English were searched. The articles were found by using the contents of the Edinburgh University library and also Internet resources provided by the library itself. Articles that could not be sourced electronically and were not available in the university library were requested from other libraries in the UK.

\section{Declaration of interest}

The authors declare that there is no conflict of interest that could be perceived as prejudicing the impartiality of this review.

\section{Funding}

This was supported by Wellbeing (R40608, 2008-10) (AWH/ HODC), Tenovus Scotland (E06/7) (AWH/HODC), The Barbour Watson Trust (AWH/HODC), NHS Lothian Research and Development (SPG2006/7) (AWH) and The Cunningham Trust (WCD).

\section{References}

Atkinson AJ, Colburn WA, DeGruttola VG, DeMets DL, Downing GJ, Hoth DF, Oates JA, Peck CC, Schooley RT, Spilker BA et al. 2001 Biomarkers and surrogate endpoints: preferred definitions and conceptual framework. Clinical Pharmacology and Therapeutics 69 89-95.

Barnhart KT, Sammel MD, Rinaudo PF, Zhou L, Hummel AC \& Guo W 2004 Symptomatic patients with an early viable intrauterine pregnancy: HCG curves redefined. Obstetrics and Gynecology 104 50-55.

Birkhahn RH, Gaeta TJ, Leo PJ \& Bove JJ 2000a The utility of maternal creatine kinase in the evaluation of ectopic pregnancy. American Journal of Emergency Medicine 18 695-697.

Birkhahn RH, Gaeta TJ, Suzuki T, Katoh H, Nagai R \& Bove J 2000 b Serum levels of smooth muscle heavy-chain myosin in patients with ectopic pregnancy. Annals of Emergency Medicine 36 101-107.

Birkhahn RH, Gaeta TJ, Paraschiv D, Bove JJ, Suzuki T, Katoh H \& Nagai R 2001 Serum levels of myoglobin, creatine phosphokinase, and smooth muscle heavy-chain myosin in patients with ectopic pregnancy. Annals of Emergency Medicine 38 628-632.

Bischof P, Reyes H, Herrmann WL \& Sizonenko PC 1983 Circulating levels of pregnancy associated plasma protein-A (PAPP-A) and human chorionic gonadotropin ( $\mathrm{hCG}$ ) in intrauterine and extrauterine pregnancies. British Journal of Obstetrics and Gynaecology 90 323-325.

Brumsted JR, Nakajima ST, Badger G, Riddick GH \& Gibson M 1990 Serum concentration of CA-125 during the first trimester of normal and abnormal pregnancies. Journal of Reproductive Medicine 35 499-502.

Buck RH, Joubert SM \& Norman RJ 1988 Serum progesterone in the diagnosis of ectopic pregnancy: a valuable diagnostic test? Fertility and Sterility 50 752-755.

Buckley RG, King KJ, Disney JD, Riffenburgh RH, Gorman JD \& Klausen JH 2000 Serum progesterone testing to predict ectopic pregnancy in symptomatic first-trimester patients. Annals of Emergency Medicine 36 95-100.

Cabar FR, Fettback PB, Pereira PP \& Zugaib M 2008 Serum markers in the diagnosis of tubal pregnancy. Clinics 63 701-708.

Cacciatore B, Stenman UH \& Ylostalo P 1994 Early screening for ectopic pregnancy in high-risk symptom-free women. Lancet 343 517-518. 
Canney PA, Moore M, Wilkinson PM \& James RD 1984 Ovarian cancer antigen CA125: a prospective clinical assessment of its role as a tumour marker. British Journal of Cancer 50 765-769.

Chandra L \& Jain A 1995 Maternal serum creatine kinase as a biochemical marker of tubal pregnancy. International Journal of Gynaecology and Obstetrics 49 21-23.

Condous G, Lu C, van Huffel SV, Timmerman D \& Bourne T 2004 Human chorionic gonadotrophin and progesterone levels in pregnancies of unknown location. International Journal of Gynaecology and Obstetrics 86 351-357.

Costa TN, Cassaro Stunz CM, Nicolau JM \& Gutierrez PS 2008 Comparison of $\mathrm{MB}$ fraction of creatine kinase mass and troponin I serum levels with necropsy findings in acute myocardial infarction. American Journal of Cardiology $101311-314$

Daily CA, Laurent SL \& Nunley WC Jr 1994 The prognostic value of serum progesterone and quantitative beta-human chorionic gonadotropin in early human pregnancy. American Journal of Obstetrics and Gynaecology 171 380-383

Daniel Y, Geva E, Lerner-Geva L, Eshed-Englender T, Gamzu R, Lessing JB Bar-Am A \& Amit A 1999 Levels of vascular endothelial growth factor are elevated in patients with ectopic pregnancy: is this a novel marker? Fertility and Sterility 72 1013-1017.

D'Antona D, Mamers PM, Lowe PJ, Balazs N, Groome NP \& Wallace EM 1998 Evaluation of serum inhibin $A$ as a surveillance marker after conservative management of tubal pregnancy. Human Reproduction 13 2305-2307.

Daponte A, Pournaras S, Zintzaras E, Kallitsaris A, Lialios G, Maniatis AN \& Messinis IE 2005 The value of a single combined measurement of VEGF, glycodelin, progesterone, PAPP-A, HPL and LIF for differentiating between ectopic and abnormal intrauterine pregnancy. Human Reproduction 20 3163-3166.

Darai E, Vlastos G, Benifla JL, Sitbon D, Hassid J, Dehoux M, Madelenat P, Durand Gaucher G \& Nunez E 1996 Is maternal serum creatine kinase actually a marker for early diagnosis of ectopic pregnancy? European Journal of Obstetrics and Gynecology 68 25-27.

Dart R, Dart L, Segal M, Page C \& Brancato J 1998 The ability of a single serum progesterone value to identify abnormal pregnancies in patients with beta-human chorionic gonadotropin values less than 1,000 $\mathrm{mIU} / \mathrm{mL}$. Academic Emergency Medicine 5 304-309.

Develioglu OH, Askalli C, Uncu G, Samli B \& Daragenli O 2002 Evaluation of serum creatine kinase in ectopic pregnancy with reference to tubal status and histopathology. British Journal of Obstetrics and Gynaecology 109 121-128.

Duncan WC, Sweeting VM, Cawood P \& Illingworth PJ 1995 Measurement of creatine kinase activity and diagnosis of ectopic pregnancy. British Journal of Obstetrics and Gynaecology 102 233-237.

Enoki Y \& Morimoto T 2000 Gizzard myoglobin contents and feeding habits in avian species. Comparative Biochemistry and Physiology. Part A, Molecular and Integrative Physiology 125 33-43.

Farquhar CM 2005 Ectopic pregnancy. Lancet 366 583-591.

Fasouliotis SJ, Spandorfer SD, Witkin SS, Liu HC, Roberts JE \& Rosenwaks Z 2004 Maternal serum vascular endothelial growth factor levels in early ectopic and intrauterine pregnancies after in vitro fertilization treatment. Fertility and Sterility 82 309-313.

Felemban A, Sammour A \& Tulandi T 2002 Serum vascular endothelial growth factor as a possible marker for early ectopic pregnancy. Human Reproduction 17 490-492.

Florio P, Severi SM, Bocchi C, Luisi S, Mazzini M, Danero S, Torricelli M \& Petraglia F 2007 Single serum activin a testing to predict ectopic pregnancy. Journal of Clinical Endocrinology and Metabolism 92 1748-1753.

Foth D \& Romer T 2003 Glycodelin serum levels in women with ectopic pregnancy. European Journal of Obstetrics and Gynecology 108 199-202.

Fraser HM \& Duncan WC 2005 Vascular morphogenesis in the primate ovary. Angiogenesis 8 101-116.

Fraser HM, Wilson H, Silvestri A, Morris KD \& Wiegand SJ 2008 The role of vascular endothelial growth factor and estradiol in the regulation of endometrial angiogenesis and cell proliferation in the marmoset. Endocrinology 149 4413-4420.
Garcia A, Skurnick JH, Goldsmith LT, Emmi A \& Weiss G 1990 Human chorionic gonadotropin and relaxin concentrations in early ectopic and normal pregnancies. Obstetrics and Gynecology 75 779-783.

Garcia-Velasco JA, Requena A \& Santisteban J 1996 Maternal serum creatine kinase: a possible predictor of tubal pregnancy? American Journal of Obstetrics and Gynaecology 175 238-239.

Gelder MS, Boots LR \& Younger JB 1991 Use of single random random serum progesterone value as a diagnostic aid for ectopic pregnancy. Fertility and Sterility 55 497-500.

Gracia CR \& Barnhart KT 2001 Diagnosing ectopic pregnancy: decision analysis comparing six strategies. Obstetrics and Gynecology 97 464-470.

Grosskinsky CM, Hage ML, Tyrey L, Christakos AC \& Hughes CL 1993 hCG, progesterone, alpha-fetoprotein, and estradiol in the identification of ectopic pregnancy. Obstetrics and Gynecology 81 705-709.

Guillaume J, Benjamin F, Sicuranza BJ, Deutsch S, Seltzer VL \& Tores W 1990 Serum estradiol as an aid in the diagnosis of ectopic pregnancy. Obstetrics and Gynecology 76 1126-1129.

Halila H, Stenman UH \& Seppala M 1986 Ovarian cancer antigen CA-125 in pelvic inflammatory disease and pregnancy. Cancer 57 1327-1329.

Handwerger S \& Freemark M 2000 The roles of placental growth hormone and placental lactogen in the regulation of human fetal growth and development. Journal of Pediatric Endocrinology and Metabolism 13 343-356.

Ho PC \& Jones WR 1980 Pregnancy-specific ß1-glycoprotein as a prognostic indicator in complications of early human pregnancy. American Journal of Obstetrics and Gynaecology 138253.

Horne CHW, Towler CM, Pugh-Humphreys RGP, Thomson AW \& Bohn H 1976 Pregnancy specific beta-1-glycoprotein - a product of the syncytiotrophoblast. Experientia 321197.

Horne AW, van den Driesche S, Critchley HOD, King AE, Burgess S, Myers M, Ludlow H, Williams AR \& Duncan WC 2008 Endometrial inhibin/activin beta-B subunit expression is related to decidualization and is reduced in tubal ectopic pregnancy. Journal of Clinical Endocrinology and Metabolism 93 2375-2382.

Illingworth PJ, Groome NP, Duncan WC, Grant V, Tovanabutra S, Baird DT \& McNeilly AS 1996 Measurement of circulating inhibin forms during the establishment of pregnancy. Journal of Clinical Endocrinology and Metabolism 81 1471-1475.

Jones EA, Clement-Jones M, James OF \& Wilson DI 2001 Differences between human and mouse alpha-fetoprotein expression during early development. Journal of Anatomy 198 555-559.

Julkunen M, Koistinen R, Sjoberg J, Rutanen EM, Wahlstrom T \& Seppala M 1986 Secretory endometrium synthesises intact placental protein 14 . Endocrinology 118 1782-1786.

Kadar N, DeVore G \& Romero R 1981 a Discriminatory hCG zone: its use in the sonographic evaluation of ectopic pregnancy. Obstetrics and Gynecology 58 156-161.

Kadar N, Caldwell BV \& Romero R $1981 b$ A method of screening for ectopic pregnancy and its indications. Obstetrics and Gynecology $\mathbf{5 8}$ 162-166.

Katoh H, Suzuki T, Yokomori K, Suzuki S, Ohtaki E, Watanabe M, Yazaki Y \& Nagai R 1995 A novel immunoassay of smooth muscle myosin heavy chain in serum. Journal of Immunological Methods 185 57-63.

Katsikis I, Rousso D, Farmakiotis D, Kourtis A, Diamenti-Kandarakis E \& Panidis D 2006 Receiver operator characteristics and diagnostic value of progesterone and CA-125 in the prediction of ectopic and abortive intrauterine gestations. European Journal of Obstetrics, Gynecology, and Reproductive Biology 125 226-232.

Kirk E, Papageorghiou AT, Van Calster B, Condous G, Bottomley C, Timmerman D, Spencer K \& Bourne T 2008 Can serial measurements of inhibin $A$ and activin A be used to predict the outcome of pregnancies of unknown location? Human Reproduction 23 (Supplement 1) i43 (Abstract from the 24th Annual Meeting of ESHRE, Barcelona, Spain, 7-9 July 2008).

Klocke FJ, Copley DP, Krawczyk JA \& Reichlin M 1982 Rapid renal clearance of immunoreactive canine plasma myoglobin. Circulation 65 1522-1528.

Korhonen J, Alfthan H, Stenman UH \& Ylostalo P 1996 Failure of creatine kinase to predict ectopic pregnancy. Fertility and Sterility 65 922-924. 
Kucera-Sliutz E, Schiebel I, Konig F, Leodolter S, Sliutz G \& Koelbl H 2002 Vascular endothelial growth factor (VEGF) and discrimination between abnormal intrauterine and ectopic pregnancy. Human Reproduction 17 3231-3234.

Kurzel RB, Mazdisnian F, Paige S \& Liu P 2001 Serum creatine kinase is not a reliable indicator of ectopic pregnancy. International Journal of Fertility and Women's Medicine 46 300-303.

Kuscu E, Vicdan K, Turhan NO, Oguz S, Zorlu G \& Gokmen O 1993 The hormonal profile in ectopic pregnancies. Materia Medica Polona 25 149-152.

Ladoux A \& Frelin C 1993 Hypoxia is a strong inducer of vascular endothelial growth factor mRNA expression in the heart. Biochemical and Biophysical Research Communications 195 1005-1010.

Lavie O, Beller U, Neuman M, Ben-Chetrit A, Gottcshalk-Sabag S \& Diamant Y 1993 Maternal serum creatine kinase: a possible predictor of tubal pregnancy. American Journal of Obstetrics and Gynaecology 169 $1149-1150$.

Lazar L, Nagy B, Ban Z, Nagy GR \& Papp Z 2006 Presence of cell-free fetal DNA in plasma of women with ectopic pregnancies. Clinical Chemistry 52 1599-1601.

Ledger WL, Sweeting VM \& Chatterjee S 1994 Rapid diagnosis of early ectopic pregnancy in an emergency gynaecology service - are measurements of progesterone, intact and free beta human chorionic gonadotrophin helpful? Human Reproduction 9 157-160.

Lenton EA, Neal LM \& Sulaiman R 1982 Plasma concentrations of human chorionic gonadotropin from the time of implantation until the second week of pregnancy. Fertility and Sterility 37 773-778.

Lewis G (Ed.) 2007 The Confidential Enquiry into Maternal and Child Health (CEMACH). Saving Mothers' Lives: reviewing maternal deaths to make motherhood safer - 2003-2005. The Seventh Report on Confidential Enquiries into Maternal Deaths in the United Kingdom. London: $\mathrm{CEMACH}$

Licht P, Neuwinger J, Fischer O, Siebzehnrubl E \& Wildt L 2001 Peripheral levels of vascular endothelial growth factor (VEGF) are higher in gonadotropin stimulated as compared to natural ovarian cycles. Experimental and Clinical Endocrinology and Diabetes 109 345-349.

Lin TM, Halbert SP \& Kiefer D 1976 Quantitative analysis of pregnancy associated plasma proteins in the human placenta. Journal of Clinical Investigation 57 466-472.

Lincoln SR, Dockery JR, Long CA, Rock WA Jr \& Cowan BD 1996 Maternal serum creatine kinase does not predict tubal pregnancy. Journal of Assisted Reproduction and Genetics 13 702-704.

Lundstrom V, Bremme K, Eneroth P, Nygard I \& Sundvall M 1979 Serum beta-human chorionic gonadotropin levels in the early diagnosis of ectopic pregnancy. Acta Obstetrica et Gynecologica Scandinavica 58 231.

Mantzavinos T, Phocas I, Chrelias H, Sarandakou A \& Zourlas PA 1991 Serum levels of steroid and placental protein hormones in ectopic pregnancy. European Journal of Obstetrics, Gynecology, and Reproductive Biology 39 117-122.

Marill KA, Ingmire TE \& Nelson BK 1999 Utility of a single Beta HCG measurement to evaluate for absence of ectopic pregnancy. Journal of Emergency Medicine 17 419-426.

Matthews CP, Coulson PB \& Wild RA 1986 Serum progesterone levels as an aid in the diagnosis of ectopic pregnancy. Obstetrics and Gynecology $\mathbf{6 8}$ 390-394.

McCord ML, Muram D, Buster JE, Arheart KL, Stovall TG \& Carson SA 1996 Single serum progesterone as a screen for ectopic pregnancy: exchanging specificity and sensitivity to obtain optimal test performance. Fertility and Sterility 66 513-516.

Meunier K, Mignot TM, Maria B, Guichard A, Zorn JR \& Cedard L 1991 Predictive value of renin assay for the diagnosis of ectopic pregnancy. Fertility and Sterility 55 432-435.

Milwidsky A, Adoni A, Miodovnik M, Segal S \& Palti Z 1980 Human chorionic gonadotropin ( $\beta$-subunit) in the early diagnosis of ectopic pregnancy. American Journal of Obstetrics and Gynaecology 136189.

Mol BW, Hajenius PJ, Ankum WM, Bossuyt PM \& van der Veen F 1997 Screening for ectopic pregnancy in symptom-free women at increased risk. Obstetrics and Gynecology 89 704-707.
Mol BW, Hajenius PJ, Engelsbel S, Ankum WM, van der Veer F, Hemrika DJ \& Bossuyt PM 1998a Serum human chorionic gonadotropin measurement in the diagnosis of ectopic pregnancy when transvaginal sonography is inconclusive. Fertility and Sterility $\mathbf{7 0}$ 972-981.

Mol BW, Lijmer JG, Ankum WM, van der Veen F \& Bossuyt PM 1998b The accuracy of single serum progesterone measurement in the diagnosis of ectopic pregnancy: a meta-analysis. Human Reproduction 13 3220-3227.

Mueller MD, Raio L, Spoerri S, Ghezzi F, Dreher E \& Bersinger NA 2004 Novel placental and nonplacental serum markers in ectopic versus normal intrauterine pregnancy. Fertility and Sterility 81 1106-1111.

Munro KI, Horne AW, Duncan WC \& Critchley HOD 2008 Features associated with time to diagnosis and management of ectopic pregnancy. Scottish Medical Journal $\mathbf{5 3} 49$.

Neufeld G, Cohen T, Gengrinovitch S \& Poltorak Z 1999 Vascular endothelial growth factor (VEGF) and its receptors. FASEB Journal 13 9-22.

O'Leary P, Nichols C, Feddema P, Lam T \& Aitken M 1996 Serum progesterone and human chorionic gonadotrophin measurements in the evaluation of ectopic pregnancy. Australian and New Zealand Journal of Obstetrics and Gynaecology 36 319-323.

Paige S \& Kurzel RB 1995 Creatine kinase and ectopic pregnancy. American Journal of Obstetrics and Gynaecology 172 1065-1066.

Pedersen JF, Sorensen S \& Ruge S 1991 Serum level of secretory endometrial protein PP-14 in intact ectopic pregnancy. British Journal of Obstetrics and Gynaecology 98414.

Petraglia F, Sawchenko P, Lim AT, Rivier J \& Vale W 1987 Localization, secretion and action of inhibin in human placenta. Science 237 187-189.

Plewa MC, Ledrick D, Buderer NF \& King RW 1998 Serum creatine kinase is an unreliable predictor of ectopic pregnancy. Academic Emergency Medicine 5 300-303.

Qasim SM, Trias A, Sachdev R \& Kemmann E 1996 Evaluation of serum creatine kinase levels in ectopic pregnancy. Fertility and Sterility $\mathbf{6 5}$ 443-445.

Rasor JL \& Braunstein GD 1977 A rapid modification of the beta-hCG radioimmunoassay. Use as an aid in the diagnosis of ectopic pregnancy. Obstetrics and Gynecology $\mathbf{5 0} 553$

Riss PA, Radivojevic K \& Bieglmayer C 1989 Serum progesterone and human chorionic gonadotropin in very early pregnancy: implications for clinical management. European Journal of Obstetrics and Gynecology 32 71-77.

Robson SJ \& O'Shea RT 1996 Undiagnosed ectopic pregnancy: a retrospective analysis of 31 'missed' ectopic pregnancies at a teaching hospital. Australian and New Zealand Journal of Obstetrics and Gynaecology 36 182-185.

Ruge S, Sorensen S, Vejtorp M \& Vejerslev LO 1992 The secretory endometrial protein, placental protein 14 , in women with ectopic gestation. Fertility and Sterility 57 102-106.

Sadovsky Y, Pineda J \& Collins JL 1991 Serum CA-125 levels in women with ectopic and intrauterine gestations. Journal of Reproductive Medicine 36 875-878.

Sealey JE, Cholst I, Glorioso N, Troffa C, Weintraub ID, James G \& Laragh JH 1987 Sequential changes in plasma luteinising hormone and plasma prorenin during the menstrual cycle. Journal of Clinical Endocrinology and Metabolism 651.

Seeber BE, Sammel MD, Guo W, Zhou L, Hummel A \& Barnhart KT 2006 Application of redefined human chorionic gonadotropin curves for the diagnosis of women at risk for ectopic pregnancy. Fertility and Sterility $\mathbf{8 6}$ $454-459$.

Segal S, Gor H, Correa N, Mercado R, Veenstra K \& Rivnay B 2008 Inhibin A: marker for diagnosis of ectopic and early abnormal pregnancies. Reproductive Biomedicine Online 17 789-794.

Seifer DB, Lambert-Messerlian GM, Canick JA, Frishman GN \& Schneyer AL 1996 Serum inhibin levels are lower in ectopic than intrauterine spontaneously conceived pregnancies. Fertility and Sterility 65 667-669.

Senturk LM \& Arici A 1998 Leukemia inhibitory factor in human reproduction. American Journal of Reproductive Immunology 39 $137-143$. 
Seppala M \& Purhonen M 1987 The use of hCG and other pregnancy proteins in the diagnosis of ectopic pregnancy. Clinical Obstetrics and Gynecology 30 148-154.

Sinosich MJ, Ferrier A, Teisner B, Porter R, Westergaard JG, Saunders DM \& Grudzinskas JG 1985 Circulating and tissue concentrations of pregnancy associated plasma protein-A (PAPP-A) in tubal ectopic gestation. Clinical Reproduction and Fertility 3 311-317.

Sjoberg J 1987 Pregnancy associated plama protein-A in pregnancy-related gynaecological emergency. Human Reproduction 2 615-616.

Soriano D, Hugol D, Quang NT \& Darai E 2003 Serum concentrations of interleukin-2R (IL-2R), IL-6, IL-8 and tumor necrosis factor alpha in patients with ectopic pregnancy. Fertility and Sterility 79 975-980.

Soundravally R, Soundara Raghavan S \& Selvaraj N 2007 Serum creatine kinase as a predictor of tubal ectopic pregnancy. International Journal of Gynaecology and Obstetrics 98 253-254.

Stabile I, Olajide F, Chard T \& Grudzinkas JG 1994 Circulating levels of placental protein 14 in ectopic pregnancy. British Journal of Obstetrics and Gynaecology 101 762-764.

Stovall TG, Ling FW, Andersen RN \& Buster JE 1992 Improved sensitivity and specificity of a single measurement of serum progesterone over serial quantitative beta-human chorionic gonadotrophin in screening for ectopic pregnancy. Human Reproduction 7 723-725.

Szlachter BN, Quagliarello J, Jewelewicz R, Osathanondh R, Spellacy WN \& Weiss G 1982 Relaxin in normal and pathogenic pregnancies. Obstetrics and Gynecology 59167.

Tay JI, Moore J \& Walker JJ 2000 Ectopic pregnancy. BMJ 320 916-919.

Tornehave D, Chemnitz J, Westergaard JG, Teisner B, Poulsen HK, Bolton AE \& Grudzinskas JG 1987 Placental proteins in peripheral blood and tissues of ectopic pregnancies. Gynecologic and Obstetric Investigation 23 97-102.

Treetampinich C, O'Connor AE, MacLachlan V, Groome NP \& de Kretser DM 2000 Maternal serum inhibin A concentrations in early pregnancy after IVF and embryo transfer reflect the corpus luteum contribution and pregnancy outcome. Human Reproduction 15 2028-2032.
Vandermolen DT \& Borzelleca JF 1996 Serum creatine kinase does not predict ectopic pregnancy. Fertility and Sterility 65 916-921.

Walker JJ 2007 Ectopic pregnancy. Clinical Obstetrics and Gynecology 50 89-99.

Walker WH, Fitzpatrick SL, Barrera-Saldana HA, Resendez-Perez D \& Saunders GF 1991 The human placental lactogen genes: structure, function, evolution and transcriptional regulation. Endocrine Reviews 12 316-328.

Wegner NT \& Mershon JL 2001 Evaluation of leukemia inhibitory factor as a marker of ectopic pregnancy. American Journal of Obstetrics and Gynaecology 184 1074-1076.

Weiss G, O'Byrne EM \& Steinetz BG 1976 Relaxin: a product of the human corpus luteum in pregnancy. Science 194 948-949.

Wen X, Tozer AJ, Li D, Docherty SM, Al-Shawaf T \& Iles RK 2008 Human granulosa-lutein cell in vitro production of progesterone, inhibin $A$, inhibin B, and activin A are dependent on follicular size and not the presence of the oocyte. Fertility and Sterility 89 1406-1413.

Witt BR, Wolf GC, Wainwright CJ, Johnston PD \& Thorneycroft IH 1990 Relaxin, CA125, progesterone, oestradiol, Schwangerschaft protein and human chorionic gonadotropin as predictors of outcome in threatened and non threatened pregnancies. Fertility and Sterility $\mathbf{5 3}$ 1029-1036.

Wodzig KW, Kragten JA, Hermens WT, Glatz JF \& van Dieijen-Visser MP 1997 Estimation of myocardial infarct size from myoglobin or fatty acidbinding protein: influence on renal function. European Journal of Clinical Chemistry and Clinical Biochemistry 35 191-198.

Yeko TR, Gorrill MJ, Hughes LH, Rodi IA, Buster JE \& Sauer MV 1987 Timely diagnosis of early ectopic pregnancy using a single blood progesterone measurement. Fertility and Sterility 48 1048-1050.

Received 18 February 2009

First decision 25 March 2009

Accepted 25 March 2009 